\title{
Calophyllum inophyllum extract as a natural enhancer for improving physical properties of bioplastics and natural antimicrobial
}

\author{
RINI UMIYATI ${ }^{1,3, \bullet}$, RIA MILLATI $^{1}$, TEGUH ARIYANTO ${ }^{2}$, CHUSNUL HIDAYAT $^{1, \bullet \bullet}$ \\ ${ }^{1}$ Department of Food and Agricultural Product Technology, Faculty of Agriculture Technology, Universitas Gadjah Mada. Jl. Flora, Sleman 55281, \\ Yogyakarta, Indonesia. Tel./fax.: +62-274-589797, ^vemail: chusnul@gadjahmada.edu \\ ${ }^{2}$ Department of Chemical Engineering, Faculty of Engineering, Universitas Gadjah Mada. J1. Teknika Utara, Sleman 55281, Yogyakarta, Indonesia \\ ${ }^{3}$ Department of Food Technology, Faculty of Engineering, University of PGRI Semarang, Jl. Sidodadi Timur No. 24, Semarang 50125, Central Java, \\ Indonesia. Tel.: +62-24-8316377, `email: riniumiyati@upgris.ac.id
}

Manuscript received: 23 April 2020. Revision accepted: 25 June 2020

\begin{abstract}
Umiyati R, Millati R, Ariyanto T, Hidayah C. 2020. Calophyllum inophyllum extracts as a natural enhancer for improving physical properties of bioplastics and antimicrobial activity. Biodiversitas 21: 3294-3302. The utilization of Calophyllum inophyllum (or nyamplung) cake (NC) is still limited, only as fertilizer and animal feed. This research aimed to evaluate C. inophyllum (or nyamplung) cake extract (NCE) and its utilization as an antimicrobial agent in packaging material. Bioplastics were prepared by the thermo-compression method. The results showed that the NC and NCE contained tannins and amide groups. They had antimicrobial activities toward Escherichia coli and Staphylococcus aureus. Only NCE had antifungal toward Aspergillus nigger. Therefore, HPS bioplastic containing NCE exhibited antibacterial. Besides, NCE and NC contained carbonyl and amide groups. As a result, NCE addition was able to significantly increase tensile strength $(\sigma)$ of bioplastic, in which it was about 1.5 times higher compared to control. But NCE did not have a significant effect on elongation at break ( $\varepsilon$ ) and modulus of elasticity (Y). Water solubility (WS) and water vapor permeability (WVP) were reduced with an increase in NCE concentration. HPS-NCE bioplastics show a finer and more homogeneous texture compared to control bioplastic. The NCE shows the ability as a natural enhancer for improving bioplastics properties as well as function as an antibacterial agent against Escherichia coli and Staphylococcus aureus bacteria in bioplastics.
\end{abstract}

Keywords: Antimicrobial activity, bioplastic, Calophyllum inophyllum, natural crosslink, nyamplung cake extract, tannin

\section{INTRODUCTION}

The main function of packaging is to isolate food products from the external environment and to protect food from damage caused by microorganisms, moisture, gas, dust, odors, and others (Kumari et al. 2017). In general, microbial contamination is the main factor in food spoilage. Various traditional methods for preserving food have been used for a long time, such as fermentation, drying, the addition of antimicrobial agents (organic acids, plants, and salt), thermal processes, freezing, cooling, atmosphere, modification, and irradiation. But these have limitations.

The current food packaging trend is a more innovative development system with an approach to inhibit the activity of pathogenic microbes in food (Sung et al. 2013; Kumari et al. 2017). Many packaging products, such as active packaging that contains antimicrobial agents, have been developed to meet food safety requirements (Malhotra et al. 2015). The use of antimicrobial packaging has more advantages compared to the direct addition of antimicrobial agents in food since the addition of antimicrobial agents directly to food was not effective in inhibiting microorganisms (Sung et al. 2013).

On the other hand, cross-linking agents are needed to improve tensile strength in bioplastics synthesis (ElTahlawy et al. 2007). There are two types of cross-linkers, which can be used, namely synthetic and natural crosslinkers. Synthetic cross-linkers are phosphor oxychloride $\left(\mathrm{POCl}_{3}\right)$, sodium trimetaphosphate (STMP), sodium tripolyphosphate (STPP), epichlorohydrin (EPI), a mixture of adipic, acetate anhydride, and a mixture of succinic anhydride and vinyl acetate (Spec-Chem Ind. 2014). Natural crosslinkers are derived from plant extract, such as tannin (Böhm et al. 2016).

Nyamplung (Calophyllum inophyllum) has various biological activities, such as piscicidal, antibacterial, hypotension, molluscicidal, antivirus, antiretroviral, and phagocytes stimulating effect (Hien et al. 2009). Because it contains flavonoid amentoflavone, steroid campesterol, arachidic fatty acid, xanthone derivates of brasilixanthone$B$ and buchanaxanthone, coumarin derivates of Calocoumarin-A, calocoumarin-B, calocoumarin- $\mathrm{C}$ and apetalolide, and triterpene's beta amyrin (Mishra et al. 2010).

Phenolic in C. inophyllum is associated with tannin, which responsible for its water solubility and possible antimicrobial activity (Sundur et al. 2014). Tannin is also a natural polyphenol and was used as a phenolic resin, additive, or water-resistant phenolic adhesive (Böhm et al. 2016). Tannin can be classified into two groups, namely hydrolyzed and condensed tannin. Hydrolyzed tannin consists of gallic ester and ellagic acid glycoside, and thus it was divided into gallotannin and ellagitannin (Falcão 
and Araújo 2011; Radebe et al. 2012; Chlebek and Jun 2014). The second group of condensed tannin or proanthocyanidin was oligomer or polymer from the basic structure of flavan-3-ol (Chlebek and Jun 2014; Grasel et al. 2016).

Tannin and phenolic reportedly exhibited antibacterial activity (Mishra et al. 2010). Tannin is a polymer from polyphenol synthesized by plants as a secondary metabolite as a protection agent. Its $\mathrm{OH}$ groups serve as an antioxidant with reducing power and unique antiradical. In contrast, its hydroxyl groups undergo intra-and intermolecular hydrogen bonds to minimize energy in the system and increase stability (Ricci et al. 2015).

From previous studies, amide and polyamide are derivatives of fatty acids and alpha-amino acids that have been widely developed as antimicrobial material and surfactants. They are effective for several microbial, such as Escherichia coli, Staphylococcus aureus, Pseudomonas aeruginosa, Micrococcus luteus, Bacillus cereus, Candida albicans (Pinazo et al. 2016).

Calophyllum inophyllum (nyamplung) cake (NC) can be used as a non-conventional feedstuff for goldfish and $100 \mathrm{~g} / \mathrm{kg}$ additional feed improved growth, performance, and nutritional use (Rath et al. 2017), all indicated that NC is safely consumed into a certain extent. The cake is the residue of seed oil extraction (Gallstedt et al. 2011). Besides, NCE was used to synthesized bioplastic (Umiyati et al. 2019) in our laboratory. Results showed that NCE at low concentration could inhibit the growth of Staphylococcus aureus and Escherichia coli. However, it reduced the mechanical properties of bioplastics. Therefore, in this study, bioplastic, which had antimicrobial activities and better mechanical properties, was prepared using hydroxypropyl, glycerol, and $C$. inophyllum (nyamplung) cake extract (NCE). This study aimed to evaluate the high concentration of $\mathrm{NCE}$ as an antimicrobial agent and a natural crosslinker for improving the mechanical properties of packaging material. The fingerprint spectra of NC, NCE, and bioplastic were analyzed by FTIR to evaluate their specific groups. NCE was also analyzed by NMR. The compositions of NC, antimicrobial activities, and mechanical properties of bioplastic were also evaluated.

\section{MATERIALS AND METHODS}

\section{Materials}

Calophyllum inophyllum cake was obtained from the biodiesel industry in Purworejo, Central Java, Indonesia. Hydroxypropyl starch (HPS) was obtained from Haihang Industry Co, LTD (Shandong Province, China). Ethanol $(96 \%)$ was obtained from Eco-green Oleo-chemicals. Gallic acid was obtained from Sigma-Aldrich. Dimethyl sulfoxide-d6, Mueller Hinton agar, potato dextrose agar were obtained from Merck. Whatman filter paper no. 1 was obtained from GE Healthcare Companies.

Three pathogenic reference bacteria and fungi, such as Staphylococcus aureus FNCC-0047 (gram-positive), Escherichia coli ATCC-35218 (gram-negative), and
Aspergillus nigger (fungi), were obtained from Biotechnology Research Center of Universitas Gadjah Mada, Yogyakarta, Indonesia.

Preparation of Calophyllum inophyllum cake extract (NCE)

Calophyllum inophyllum cake was dried until moisture content below 10-15\%. Dried seed NC was further milled, sifted using 120 mesh sieve, and stored in a desiccator for further treatments. NCE extraction was performed based on (Chana-Thaworn et al. 2011). Approximately $20 \mathrm{~g}$ of NC powder was added to $120 \mathrm{ml} 96 \%$ ethanol and mixed at $80^{\circ} \mathrm{C}$ for $1 \mathrm{~h}$. The mixture was filtered using Whatman paper number 1 . The filtrate was then evaporated and dried in $50^{\circ} \mathrm{C}$ oven dryer for $24 \mathrm{~h}$. The obtained NCE was stored in a desiccator prior to treatments and analyses.

\section{Preparation of bioplastic}

Calophyllum inophyllum cake extract at various concentrations $(5 \%, 10 \%, 15 \%$, and $20 \% \mathrm{w} / \mathrm{w} \mathrm{db})$ was mixed with $10 \mathrm{~g}$ HPS, $1.5 \mathrm{~g}$ glycerol, and $1 \mathrm{~g}$ distilled water. The mixture was then mixed at $21,000 \mathrm{rpm}$ for 45 min until homogeneous. Briefly, the mixture was placed in the middle of $0.5 \mathrm{~mm}$ thick aluminum $(10 \times 10 \mathrm{~cm})$. Furthermore, it was put in a thermo-compression machine and pressed at $140^{\circ} \mathrm{C}$ and $250 \mathrm{~kg} / \mathrm{m}^{2}$ pressure for $6 \mathrm{~min}$ (Rasheed et al. 2015).

Fingerprint spectra of Calophyllum inophyllum cake, $C$. inophyllum cake extract, and bioplastic Spectra of ${ }^{13} \mathrm{C}$ Nuclear Magnetic Resonance $\left({ }^{13} \mathrm{C} N \mathrm{NM}\right)$

${ }^{13}$ C Nuclear Magnetic Resonance Spectra of NCE was analyzed using Spectroscopy ${ }^{13} \mathrm{C}$ NMR according to Seelig (2010). The mixture was homogenized after the addition of $700 \mu \mathrm{L}$ DMSO d6 to $100 \mathrm{~g}$ solvent-free extract. It was then injected into the NMR tube and put in auto-sampler.

\section{Spectra of Fourier Transform Infrared Spectroscopy (FTIR)}

Fourier Transform Infrared (FTIR) Spectra of NC, NCE, and bioplastics were also analyzed using FTIR according to Detduangchan et al. (2014). Gallic acid was used as the standard for tannin analysis.

\section{Antimicrobial activity}

Antimicrobial activities of NC, NCE, and bioplastic were analyzed using the Disk-diffusion method (Balouiri et al. 2016). As much as $0.1 \mathrm{ml} 10 \%$ bacteria (Staphylococcus aureus (gram-positive), Escherichia coli (gram-negative)), and fungi (Aspergillus nigger) suspensions were inoculated in Mueller Hinton Agar and on Potato Dextrose Agar media, respectively. The sterile disk ( $\pm 6 \mathrm{~mm}$ diameter) was put into a $20 \mu \mathrm{L}$ test sample. It was further dried and put on the surface of the agar in a petri dish before it was inoculated with bacteria or fungi. Incubation was performed at $37^{\circ} \mathrm{C}$ for $1-2$ days for bacteria, and $30^{\circ} \mathrm{C}$ for 2-3 days for fungi.

\section{Physical properties of bioplastic \\ Mechanical analysis}

Tensile strength $(\sigma)$, elongation at break $(\varepsilon)$, and modulus of elasticity (Y) were measured according to 
ASTM D 638. Bioplastic was incubated at $40 \pm 5 \mathrm{RH}$ and $28{ }^{\circ} \mathrm{C}$ for $48 \mathrm{~h}$ in the humidity-controlled chamber (Zubeldía et al. 2015). The specimen was cut according to ASTM D 1708 with a constant pull speed of $5 \mathrm{~mm} / \mathrm{min}$. The tensile test was done at room temperature using Brookfield USA, texture analyzer.

\section{Water solubility analysis}

Water solubility was measured by soaking a dried bioplastic sheet in $50 \mathrm{ml}$ distilled water. It was then placed in a shaker incubator at $25^{\circ} \mathrm{C}$ for $6 \mathrm{~h}$. Pieces of bioplastic were then taken and dried at $105{ }^{\circ} \mathrm{C}$ for $24 \mathrm{~h}$ to determine the amount of soluble material in water and it was expressed in percentage (Hassannia-kolaee et al. 2016; Kumari et al. 2017).

\section{Water vapor permeability analysis}

Water vapor permeability (WVP) was analyzed based on the standard method by ASTM (1996) E 96. Bioplastic was put on permeation cells containing distilled water (31\% RH). It was placed in desiccator that previously poured with silica gel $(0 \% \mathrm{RH})$ and stored at $26.9^{\circ} \mathrm{C}$. The sample was weighed every $30 \mathrm{~min}$ for $3 \mathrm{~h}$. WVP was determined using the formula below:

$$
W V P=\frac{W V T R}{P s(R H 1-R H 2)} X \delta m
$$

Where: WVP: water vapor permeability (g.mm/KPa.s.m²); WVTR: water vapor transmission rate (g/s.m $\left.{ }^{2}\right)$; Ps: saturated water vapor pressure $(\mathrm{Pa}) ; \mathrm{RH}_{1}$ : Relative Humidity in the desiccator; $\mathrm{RH}_{2}$ : Relative Humidity outside of the desiccator; $\delta m$ average thickness of bioplastic coating (m) (Wirawan et al. 2012).

\section{Scanning Electron Microscopy}

SEM was used to analyze the micro-plastic structure. The sample was stored in a desiccator containing $\mathrm{P}_{2} \mathrm{O}_{5}$ (phosphorus pentoxide) for two weeks to ensure no moisture in the sample. Bioplastic was frozen in $\mathrm{N}_{2}$ and cryo-fracture prior to cross-section observation (Espinel et al. 2014). All samples were placed in the bronze stub and covered with gold sheets before analysis. Micrography of bioplastic and fracture surface were obtained using SEM (JSM-6510 LA) at 10-300.000x magnification and 1-10 nm resolution.

\section{Data analysis}

The experimental design was a completely randomized design with the comparative treatment of HPS concentrations and variations of $C$. inophyllum cake extract $(0,5,10,15$, and 20\%). Each sample was repeated three times (treatment) and triple analyzes. Data were analyzed using variance analysis method (ANOVA) at 95\% confidence level and followed by Duncan's Multiple Range Test (DMRT) if there were significant differences.

\section{RESULTS AND DISCUSSION}

\section{Composition of Calophyllum inophyllum cake}

Table 1 shows the composition of NC powder. NC mostly contained carbohydrate (by difference). However, protein and starch contents were still low $(<20 \%)$. NC protein was lower compared to Rath et al. (2017), in which it was $24.2 \%$. It is suggested that the concentration of natural biodegradable materials, such as starch and protein, are high for bioplastic synthesis (Plackett 2011; Peelman et al. 2013; Wang 2015). Therefore, the utilization of NC is limited as a base material for bioplastics synthesis.

NC powder contained tannin (Table 1). This result is similar to Sulianti et al. (2005). It is suggested that tannin has an antimicrobial activity due to astringent property that induces a complexion with the microbial enzyme or substrate, as well as another tannin antimicrobial mechanism in different microorganisms (dos Santos et al. 2017). However, the tannin in NC was still low as an antimicrobial agent. Therefore, the utilization of tannin and other materials in NC was done by the extraction of those materials. Moreover, plant extract has a growing interest both in industry and scientific research because of antibacterial, antifungal, antiviral, and anti-parasitic properties. Some antimicrobial compounds that naturally occur in plants were incorporated in food (Chana-Thaworn et al. 2011).

\section{${ }^{13} \mathrm{C}$ Nuclear Magnetic Resonance Spectroscopy $\left({ }^{13} \mathrm{C}\right.$ NMR Spectroscopy) of Calophyllum inophyllum Cake Extract}

Figure 1 shows that the NCE spectrum was consisting of 20 signals. The peak signal at $193.5 \mathrm{ppm}$ was derived as $\mathrm{C}=\mathrm{O}$ from aldehyde/ketone. The peaks signal at $174.6 \mathrm{ppm}$, $174.3 \mathrm{ppm}, 173.7 \mathrm{ppm}, 158.7 \mathrm{ppm}, 151.7 \mathrm{ppm}$, and 151.3 ppm were derived as $\mathrm{C}=\mathrm{O}$ from ester/amide/carboxyl. Peaks at $145.1 \mathrm{ppm}, 139.3 \mathrm{ppm}, 127.7 \mathrm{ppm}$, and 104.2 were derived as $\mathrm{C}=\mathrm{C}$ from alkene/aromatic. A peak at 92.0 ppm was derived as $\mathrm{C} \equiv \mathrm{C}$ from alkenyl. The peak signals at $72.7 \mathrm{ppm}, 64.0 \mathrm{ppm}$, and $52.5 \mathrm{ppm}$ or $\mathrm{C}-\mathrm{N}$ were derived as $\mathrm{C}-\mathrm{O}$ from $\mathrm{C}-\mathrm{O}$ or $\mathrm{C}-\mathrm{N}$. A peak at $44.7 \mathrm{ppm}$ was obtained as C-N from C-N. Peaks at 39.5 ppm, a 29.3 ppm, and at 18.6, 10.6, and $9.1 \mathrm{ppm}$ were derived as $\mathrm{C}-\mathrm{H}$ or $\mathrm{C}-\mathrm{H}_{2}, \mathrm{C}-\mathrm{H}_{2}$, and $\mathrm{C}-\mathrm{H}_{3}$ from alkyl, respectively.

Table 1. Composition of Calophyllum inophyllum cake

\begin{tabular}{ll}
\hline Composition & Content $(\boldsymbol{\%})$ \\
\hline Moisture & $10.33 \pm 0.06$ \\
Ash & $9.03 \pm 0.03$ \\
Fat & $2.37 \pm 0.01$ \\
Protein & $19.01 \pm 0.60$ \\
Crude fiber & $23.77 \pm 0.31$ \\
Carbohydrate (by difference) & $59.26 \pm 0.69$ \\
Starch & \\
$\quad$ Amylose & $1.83 \pm 0.08$ \\
$\quad$ Amylopectin & $15.78 \pm 0.04$ \\
Tanin & $4.31 \pm 0.04$ \\
\hline
\end{tabular}




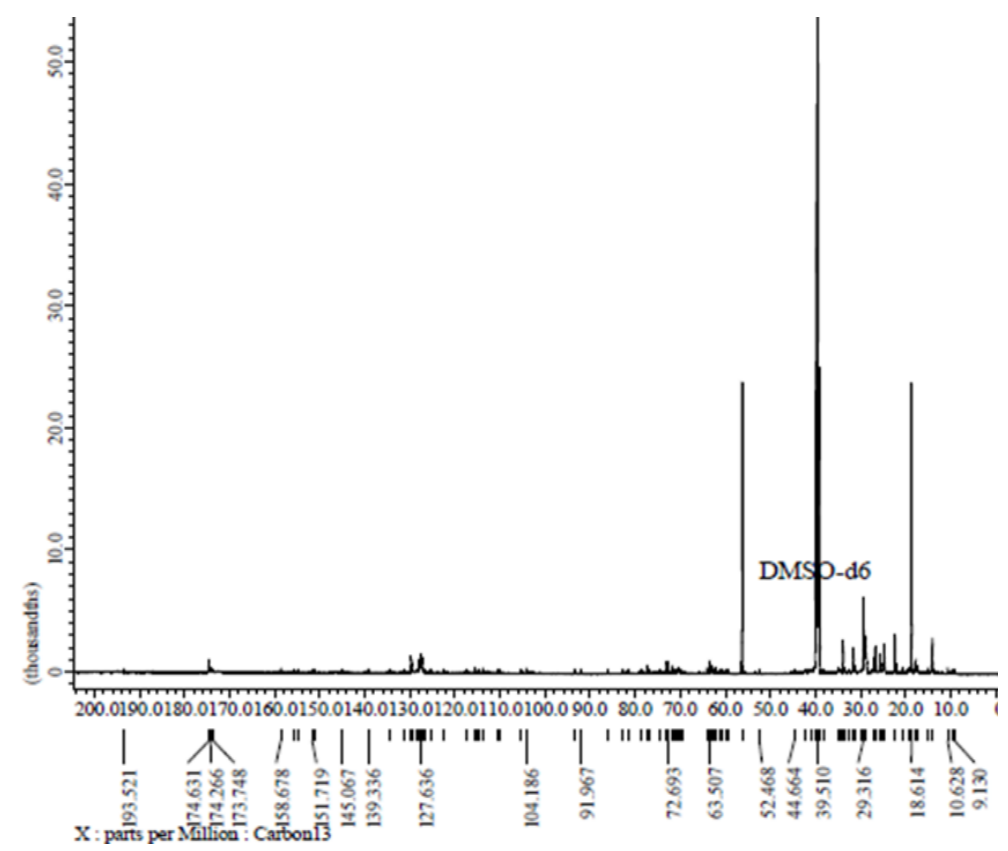

Figure 1. The spectrum of ${ }^{13} \mathrm{C}$ NMR of NCE

${ }^{13} \mathrm{C}$ NMR spectrum of NCE showed that NCE might be contained tannins and amide, in which tannins and amide were characterized by the presence of carbonyl groups $(\mathrm{C}=\mathrm{O})$ at the peaks of $174.6 \mathrm{ppm}, 174.3 \mathrm{ppm}, 173.7 \mathrm{ppm}$, $158.7 \mathrm{ppm}, 151.7 \mathrm{ppm}$, and $151.3 \mathrm{ppm}$ that are known as ester/amide/carboxyl. Amide also characterized by C-N bonds at peaks of $72.7 \mathrm{ppm}, 64.0 \mathrm{ppm}, 52.5 \mathrm{ppm}$, and 44.7 ppm. These findings are also supported by the results of FTIR analysis (Figure 2).

\section{FTIR analysis on Calophyllum inophyllum cake and $C$.} inophyllum cake extract

FTIR analysis was used to evaluate the important component in $\mathrm{NC}$ and $\mathrm{NCE}$, especially the presence of tannins and amide, and to support the ${ }^{13} \mathrm{C}$ NMR analysis of NCE. Figure 2 shows the FTIR spectrum of NC dan NCE compared to gallic acid. The presence of tannin compounds in the material is characterized by the presence of hydroxyl $(\mathrm{OH})$, carbonyl $(\mathrm{C}=\mathrm{O})$, ether, ester, and aromatic system (Ajuong and Breese 1998; Gonultas and Ucar 2012).

The peak region of the fingerprint area for the tannin of the FTIR spectrum is shown in Table 1. The results show that tannins in NC and NCE were characterized by hydroxyl $(\mathrm{OH})$ groups that show in peaks $3292.95 \mathrm{~cm}^{-1}$ for $\mathrm{NC}$, at $3356.52 \mathrm{~cm}^{-1}$ for NCE and $3330.06 \mathrm{~cm}^{-1}$ for gallic acid. C-H stretching vibration as aldehyde derived from alkanes (alkyl groups) that show at $2853.76 \mathrm{~cm}^{-1}$ for NCE and $2881.80 \mathrm{~cm}^{-1}$ for gallic acid. C-C stretching vibration derived from alkynes that show at $2113.74 \mathrm{~cm}^{-1}$ for $\mathrm{NC}$, at $2037.38 \mathrm{~cm}^{-1}$ for NCE, and $2127.70 \mathrm{~cm}^{-1}$ for gallic acid. Aromatic groups that show at $1983.25 \mathrm{~cm}^{-1}$ and 1962.47 $\mathrm{cm}^{-1}$ for NC, at $1982.00 \mathrm{~cm}^{-1}$ for NCE and $1924.86 \mathrm{~cm}^{-1}$ for gallic acid. Carbonyl $(\mathrm{C}=\mathrm{O})$ group derived from aldehyde that shows at $1721.10 \mathrm{~cm}^{-1}$ for $\mathrm{NC}$ and at $1686.89 \mathrm{~cm}^{-1}$ for gallic acid. Carbonyl $(\mathrm{C}=\mathrm{O})$ groups derived from ester show in peaks at $1601.06 \mathrm{~cm}^{-1}$ for NCE and $1571.53 \mathrm{~cm}^{-1}$ for gallic acid. Carbonyl $(\mathrm{C}=\mathrm{O})$ groups derived from amide that show at $1517.80 \mathrm{~cm}^{-1}$ for $\mathrm{NC}$, at $1516.34 \mathrm{~cm}^{-1}$ for NCE, and 1532.15 for gallic acid. C-O stretching vibration derived from the ether that shows at $1026.71 \mathrm{~cm}^{-1}$ for $\mathrm{NC}$, $1047.54 \mathrm{~cm}^{-1}$ for NCE, and $1087.08 \mathrm{~cm}^{-1}$ for gallic acid.

Thus FTIR spectrum of the fingerprint area of NC and NCE, which are compared to gallic acid, show that the fingerprint areas of both $\mathrm{NC}$ and NCE were similar to gallic acid. It indicated that NC and NCE contained tannin.

\section{Antimicrobial analysis of NC and NCE}

So far, tannins and amide were known to have antimicrobial activities against bacteria, fungi, and other pathogens (Shahat and Marzouk 2013). Tannin has hydroxyl groups and double bond $\alpha-\beta$ that were responsible for its antimicrobial properties (Elfirta et al. 2018). The presence of tannins and amides in NCE (Figures 1 and 2) was expected as an antimicrobial agent that can be used in bioplastics. The antimicrobial analysis shows that $\mathrm{NC}$ and NCE had an inhibition zone for E. coli about $7.67 \mathrm{~mm}$ and $11 \mathrm{~mm}$, respectively. For $S$. aureus, they had an inhibition zone of about $9 \mathrm{~mm}$ and $10 \mathrm{~mm}$, respectively. For $A$. nigger, it had inhibition zone $2.5 \mathrm{~mm}$ for NCE, but it was not detected for NC. It is suggested that antimicrobial activities were most likely caused by synergy or individual effect from phytoconstituents in NC (Mishra et al. 2010). C. inophyllum's antimicrobial activity is presumably associated with the presence of phenolic (Rana et al. 2017), such as tannin. However, this study indicated that antimicrobial activities of NC are more sensitive to bacteria than fungi. Lower antimicrobial activity of $\mathrm{NC}$ on fungi may be caused by the structure of fungi cell walls, which contains thicker chitin (Abu et al. 2016), and the concentration of amide in NC is still not enough to inhibit the growth of fungi. 


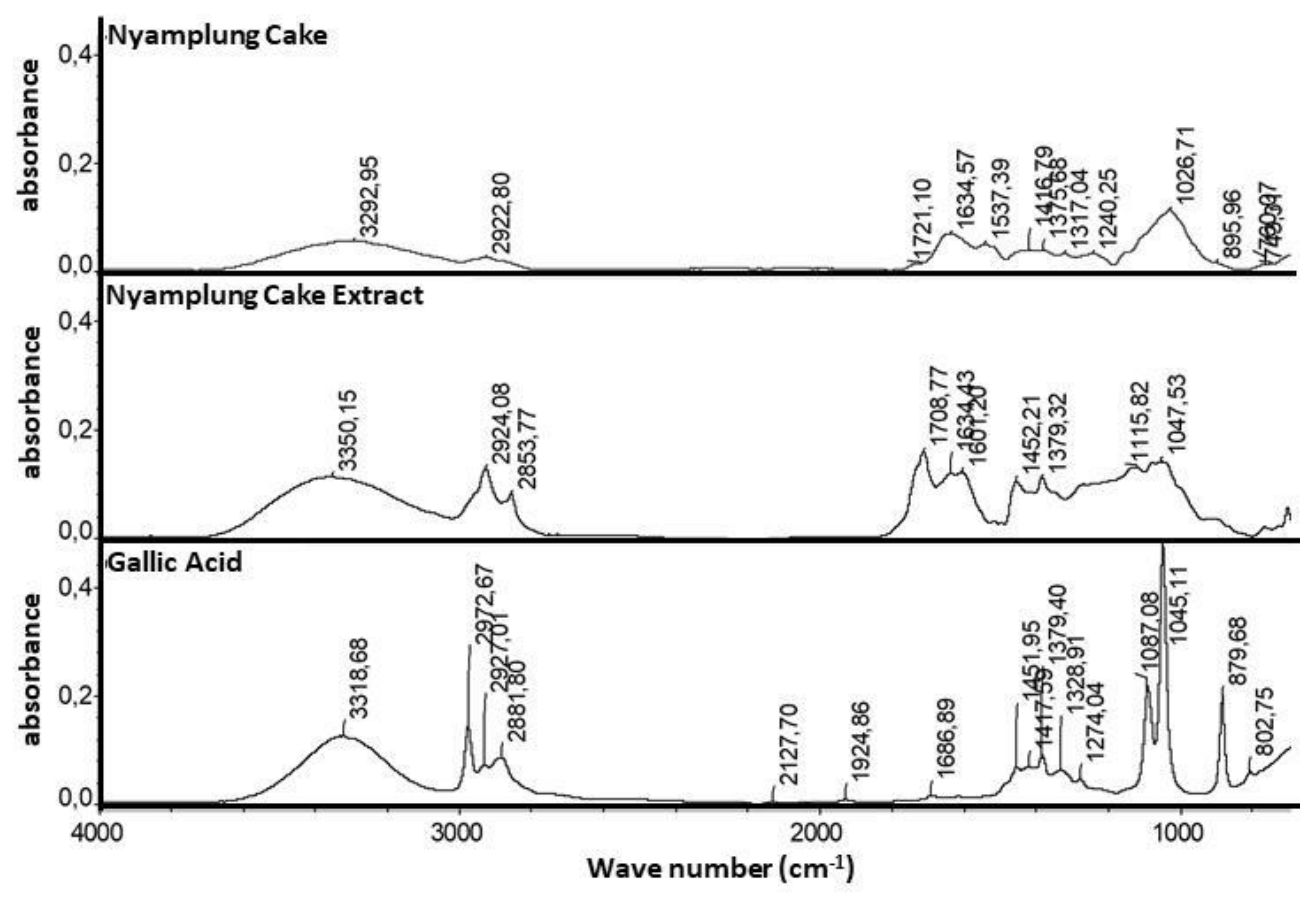

Figure 2. FTIR spectrum of NC, NCE, and gallic acid

Table 2. FTIR spectrum of the fingerprint area of NC, NCE compared to gallic acid as commonly a standard for tannin analysis

\begin{tabular}{|c|c|c|c|c|c|c|}
\hline $\begin{array}{l}\mathrm{NC} \\
\mathbf{c m}^{-1}\end{array}$ & Assignment & $\begin{array}{l}\text { NCE } \\
\mathbf{c m}^{-1}\end{array}$ & Assignment & $\begin{array}{l}\text { Gallic } \\
\text { acid }\end{array}$ & Assignment & Reference \\
\hline 3292.95 & $\begin{array}{l}\mathrm{s} ; \mathrm{O}-\mathrm{H} \text { stretching } \\
\text { vibration (associated) }\end{array}$ & 3356.52 & $\begin{array}{l}\mathrm{s} ; \mathrm{O}-\mathrm{H} \text { stretching } \\
\text { vibration (associated) }\end{array}$ & 3330.06 & $\begin{array}{l}\mathrm{s} ; \mathrm{O}-\mathrm{H} \text { stretching } \\
\text { vibration (associated) }\end{array}$ & Socrates (2004) \\
\hline 2269.91 & $\begin{array}{l}\mathrm{w}-\mathrm{m} ; \mathrm{CN} \text { stretching } \\
\text { vibrations } \\
-\mathrm{C} \equiv \mathrm{N}\end{array}$ & 2853.76 & $\begin{array}{l}\text { w; C-H stretching } \\
\text { vibration } \\
\text {-CHO }\end{array}$ & 2881.80 & $\begin{array}{l}\text { w; C-H stretching } \\
\text { vibration } \\
-\mathrm{CHO}\end{array}$ & $\begin{array}{l}\text { McMurry (2004; } \\
\text { Socrates 2004) }\end{array}$ \\
\hline 2113.74 & $\begin{array}{l}\text { w-m; } \mathrm{CC} \text { stretching } \\
\text { vibration } \\
-\mathrm{C} \equiv \mathrm{CH}\end{array}$ & 2037.38 & $\begin{array}{l}\text { vs; broad, asym. CC } \\
\text { stretching vibration } \\
\end{array}$ & 2127.70 & $\begin{array}{l}\text { w-m; CC stretching } \\
\text { vibration } \\
-\mathrm{C} \equiv\end{array}$ & $\begin{array}{l}\text { McMurry (2004; } \\
\text { Socrates 2004) }\end{array}$ \\
\hline 1983.25 & Aromatic system & 1982.00 & Aromatics system & 1924.86 & aromatic system & Socrates (2004) \\
\hline 1962.47 & Aromatic system & 170876 & & & & Socrates (2004) \\
\hline & s: unsaturated & $1 / 08.10$ & $\mathrm{~s} ; \mathrm{O}$ & 1686.89 & & $\begin{array}{l}\text { MclMurry }(2004 \text {; } \\
\text { Socrates 2004) }\end{array}$ \\
\hline 1537.39 & $\begin{array}{l}\mathrm{s}: \mathrm{N} \text {-monosubstituted } \\
\text { amide in solution } \\
\mathrm{O}\end{array}$ & 1601.06 & $\mathrm{~s} ;$ & 1571.53 & $\mathrm{~s}$ & Socrates (2004) \\
\hline 1517.80 & $\begin{array}{l}\mathrm{s}: \mathrm{N} \text {-monosubstituted } \\
\text { amide in solution } \\
\mathrm{O}\end{array}$ & 1516.34 & $\begin{array}{l}\mathrm{s} ; \mathrm{N} \text {-monosubstituted } \\
\text { amides in solution } \\
\mathrm{O} \\
\|\end{array}$ & 1532.15 & $\begin{array}{l}\mathrm{s} ; \mathrm{N} \text {-monosubstituted } \\
\text { amides in solution } \\
\quad \mathrm{O}\end{array}$ & Socrates (2004) \\
\hline 1026.71 & & 1047.54 & & 1087.08 & & $\begin{array}{l}\text { McMurry (2004; } \\
\text { Socrates 2004) }\end{array}$ \\
\hline
\end{tabular}




\section{FTIR analysis of bioplastics}

FTIR spectroscopy of bioplastic was analyzed to determine intermolecular interaction that occurs between HPS, NCE, and glycerol. Figure 3 shows the FTIR spectroscopy of five bioplastic samples. FTIR spectrum shows that a wide peak between 3284.19 and $3299.94 \mathrm{~cm}^{-1}$ was hydroxyl $(\mathrm{OH})$ group stretching. Hydroxyl $(\mathrm{OH})$ groups were probably derived from HPS, NCE, glycerol, and distilled water (Piermaria et al. 2011; Kim et al. 2017). Peaks zone at $2923.80-2930.77 \mathrm{~cm}^{-1}$ were $\mathrm{CH}_{3}$ vibration stretching ketones. These groups in the NCE backbone might be an organic compound (Agbor et al. 2011). Furthermore, the peaks at $1706.14 \mathrm{~cm}^{-1}$ and $1704.17 \mathrm{~cm}^{-1}$ occurred only by the addition of 15\% NCE and 20\% NCE, respectively. The peaks showed the presence of a carbonyl $(\mathrm{C}=\mathrm{O})$ group that derived from amide. Thus the peaks were as markers and differentiator among bioplastics peaks. The abundance of the amide is present in nature, and nitrogen that is directly bound to carbon in the carbonyl group (Pinazo et al. 2016).

Ether groups were observed at the peak zone of $1240.78-1241.21 \mathrm{~cm}^{-1}, 1102.93-1103.57 \mathrm{~cm}^{-1}$, and 1077.41$1078.89 \mathrm{~cm}^{-1}$. These indicated the presence of ether in HPS and NCE. Ether can be used as a crosslinking agent in the synthesis of bioplastic. This finding is supported by the fact that all bioplastic samples, both bioplastics control and bioplastics with the addition of NCE, show the presence of ether groups. In the manufacture of HPS, the crosslinking agent is generally occurred by treating starch (semi-dry or slurry) with reagents that can form ether or ester bonds between hydroxyl groups $(\mathrm{OH})$ on starch molecules (Manoi and Rizvi 2010).

\section{Mechanical properties}

The effect of the addition of NCE on mechanical properties $(\sigma, \varepsilon$, and $Y)$ of the bioplastics was evaluated (Figure 4). NCE addition was able to increase $\sigma$ of bioplastic significantly, but it did not have a significant effect on $\varepsilon$ and $Y$. The largest increase in $\sigma$ was obtained at the addition of $20 \%$ extract, in which it was about 1.5 times higher compared to control. The lowest increase in $\sigma$ was received at the addition of a $5 \%$ extract. These results were better than the previous study (Umiyati et al. 2019), in which $\sigma$ increased by about $2.38 \%$, and $\varepsilon$ decreased by about $3.78 \%$.

It is suggested that NCE contains carbonyl groups derived from tannins and amides, and has many hydroxyl $(\mathrm{OH})$ groups (Figure 2 and 3). Polymers that contained carbonyl groups can form hydrogen bonds between adjacent chains (McMurry 2004). So that NCE can function as a plasticizer and crosslinker. The presence of many hydroxyls $(\mathrm{OH})$ and hydrocarbon $(\mathrm{CH})$ groups, causing hydroxyl groups to be nucleophile that make it easy to attract $\mathrm{H}$ atoms in the chains (McMurry 2004). Thus the addition of NCE can reduce the concentration of starch hydroxyl groups in bioplastic, which can reduce the effect of interference on starch chains to reduce the stiffness and flexibility of bioplastics (Piermaria et al. 2011).

\section{Water Solubility (WS) and Water Vapor Permeability of Bioplastics (WVP)}

Figure 5 shows water solubility (WS) and water vapor permeability (WVP) of five sample HPS-NCE bioplastics. WS and WVP are important properties of bioplastics for application in food protection (Al-Balakocy and Shalaby 2018) because bioplastics will always come in contact with water and air during the food protection process. WS was significantly reduced with an increase in NCE concentration. Bioplastic control had the highest WS $(24.34 \pm 0.19 \%)$. The addition of $5 \%$ NCE reduced WS about $5.9 \%$. The highest WS was found in bioplastics at the addition of $5 \%$ NCE, namely about $22.26 \pm 0.22 \%$. The smallest was found in the addition of $20 \%$ NCE, namely about $19.24 \pm 0.07 \%$ (Figure 5). Compared to the previous study (Umiyati et al. 2019), WS decreased as much as $23.2 \%$. Furthermore, the addition of 5\% NCE reduced WVP of bioplastics about $22.3 \%$. An increase in NCE to $20 \%$ resulted in a decrease in WVP about $38.4 \%$.

\section{Scanning Electron Microscopy (SEM)}

The morphology of bioplastics was investigated by SEM. Figure 6 shows that the addition of NCE did not have a significant difference in its homogeneity and texture. However, HPS-NCE bioplastics show a finer and more homogeneous texture compared to control bioplastic. This result was different from (Chana-Thaworn et al. 2011), in which the addition of Kiam wood extract to HPMC film was less uniform and not completely homogeneous because it formed small aggregates in HPMC film with the addition of $1500 \mathrm{mg}$ Kiam wood extract.

\section{Antimicrobial analysis of bioplastic}

The antimicrobial analysis was performed to evaluate the ability of bioplastics to protect food from harmful pathogens. Table 3 shows that the inhibition zone was observed by the addition of 5\% NCE. An increase in NCE to $15 \%$ caused a significant increase in the clear zone on E. coli and S. aureus. Further increase in NCE to $20 \%$ did not have a significant increase in the clear zone. However, a clear zone was not detected in A. Niger. It indicated that the addition of NCE in the synthesis of HPS bioplastic exhibited antibacterial against E. coli and $S$. aureus. However, they did not exhibit antifungal toward A. nigger, while control did not have antimicrobial and antifungal activities.

Table 3. Antimicrobial analysis of $\operatorname{HPS}-\operatorname{NCE}(0,5,10,15$, and $20 \%$ ) bioplastics

\begin{tabular}{lccc}
\hline \multirow{2}{*}{ Sample } & \multicolumn{3}{c}{ Inhibition zone (mm) } \\
\cline { 2 - 4 } & E. coli & S. aureus & A. nigger \\
\hline Control & ND & ND & ND \\
Bioplastic + extract 5\% & $3.72 \pm 0.26 \mathrm{a}$ & $3.37 \pm 0.32 \mathrm{a}$ & ND \\
Bioplastic + extract 10\% & $4.42 \pm 0.40 \mathrm{~b}$ & $3.97 \pm 0.15 \mathrm{~b}$ & ND \\
Bioplastic + extract 15 \% & $5.01 \pm 0.45 \mathrm{c}$ & $4.00 \pm 0.10 \mathrm{c}$ & ND \\
Bioplastic + extract 20\% & $5.07 \pm 0.20 \mathrm{c}$ & $4.32 \pm 0.25 \mathrm{c}$ & ND \\
\hline
\end{tabular}




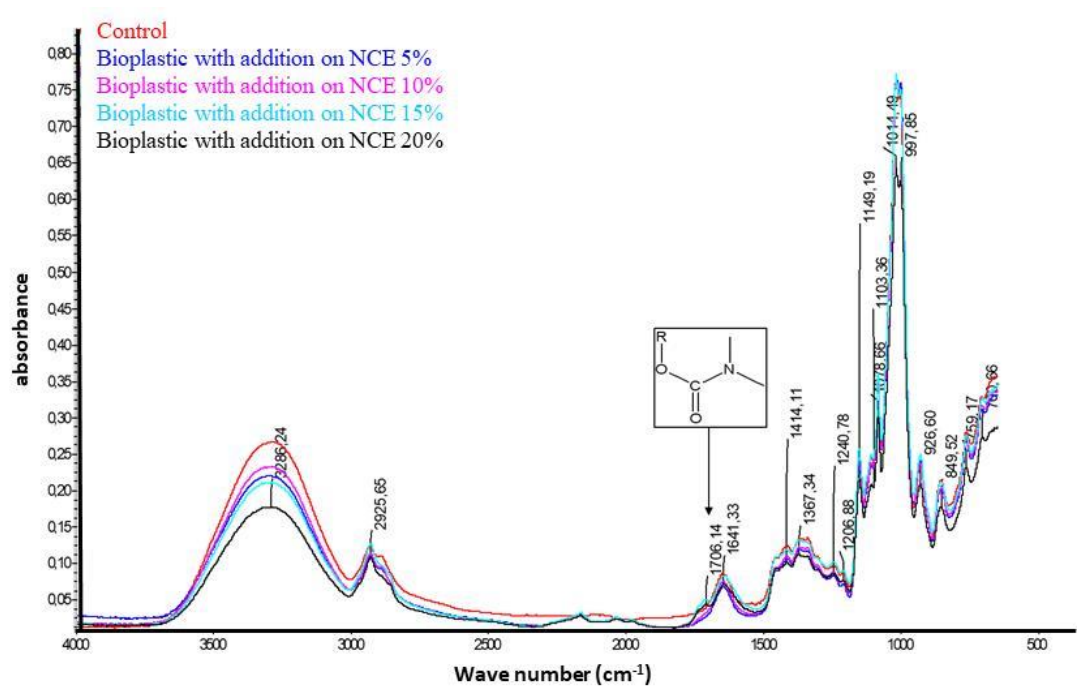

Figure 3. FTIR Spectrum of Five Bioplastics HPS-NCE at various NCE concentration (0, 5, 10, 15 and 20\%)

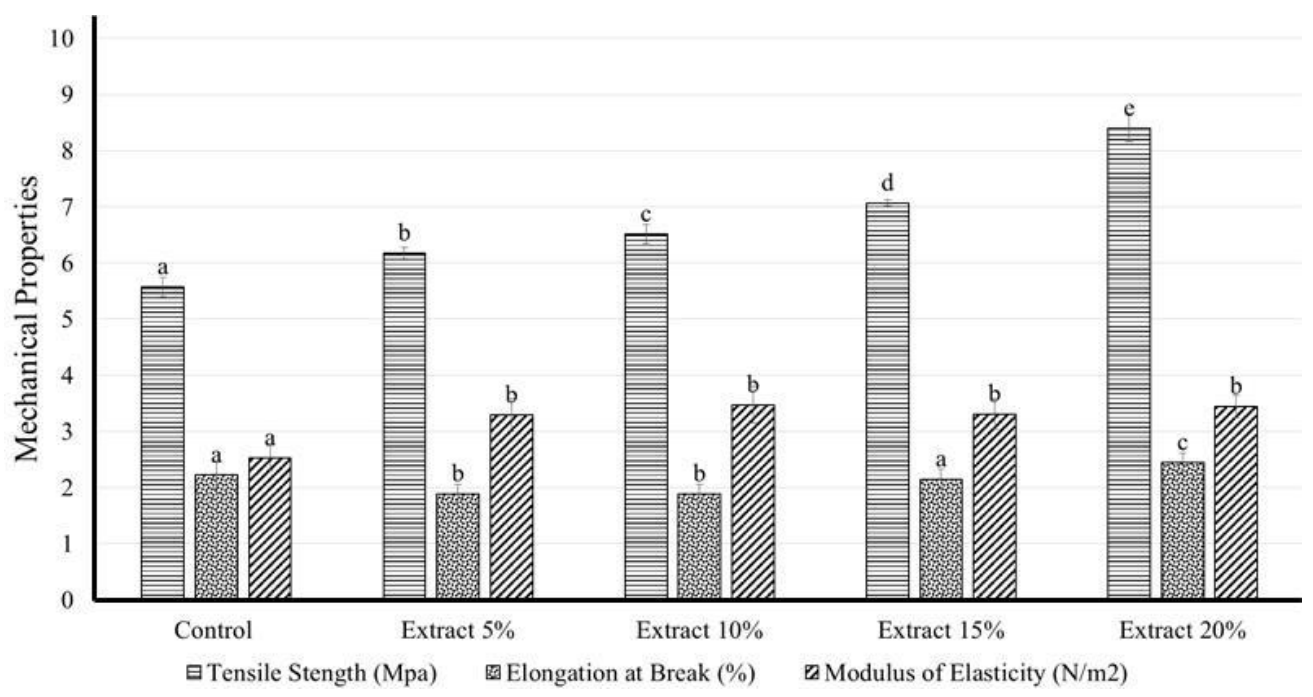

Figure 4. Tensile strength $(\sigma)$, Elongation at break $(\varepsilon)$, and Modulus of elasticity (Y) of HPS - NCE (0, 5, 10, 15, and 20\%) bioplastics, error standard is a standard error of an average of forty-five measurements from five separate bioplastics. The different letter indicates significantly different groups determined by the Duncan test $(\mathrm{p}<0.05)$.

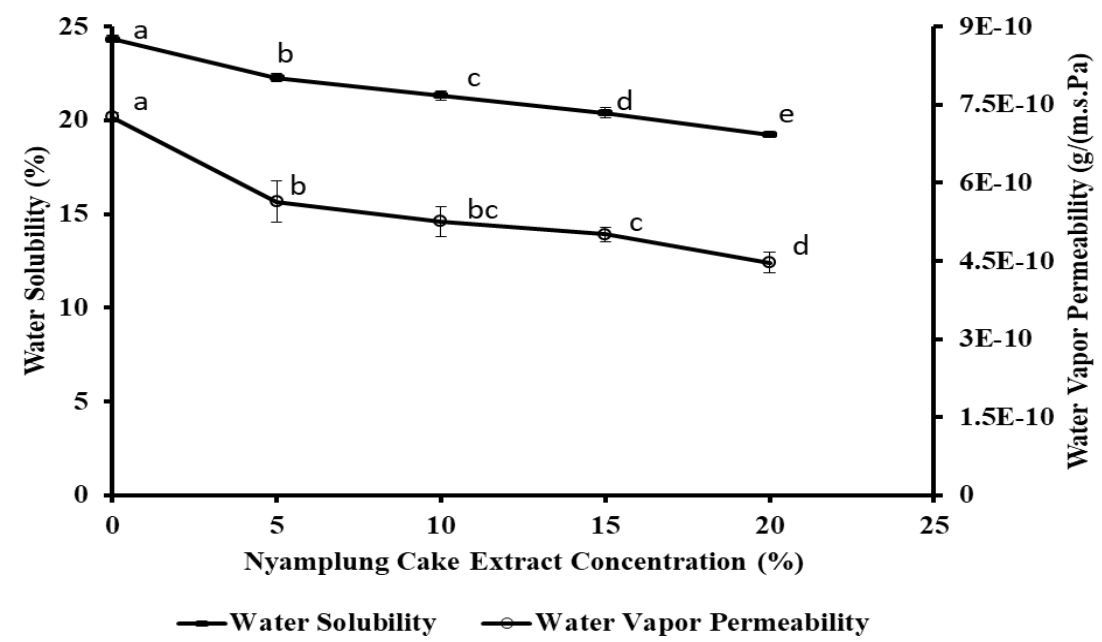

Figure 5. Effect of Calophyllum inophyllum cake extract on water solubility (WS) and water vapor permeability (WVP) of HPS-NCE bioplastics. The different letter indicates significantly different groups determined by the Duncan test $(\mathrm{p}<0.05)$. 


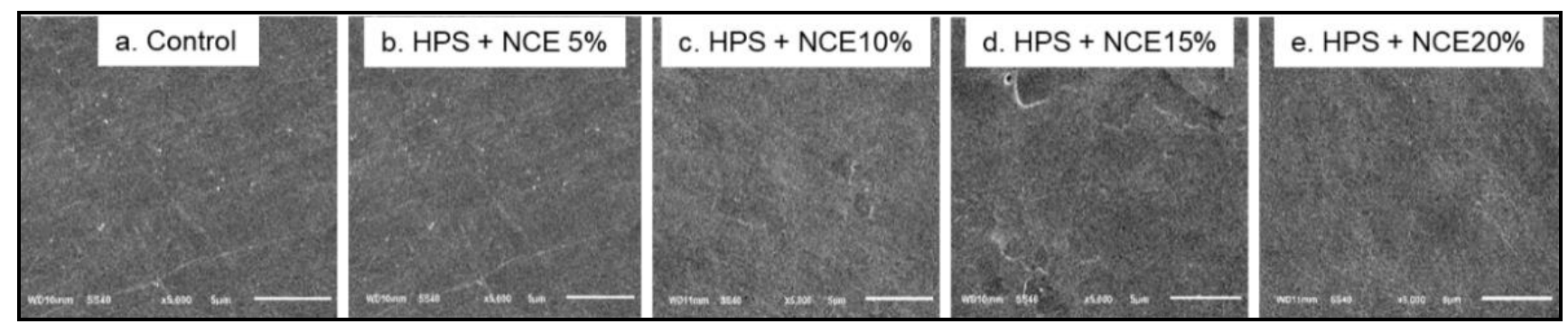

Figure 6. Scanning Electron Microscopy of $\operatorname{HPS}-\operatorname{NCE}(0,5,10,15$, and 20\%) bioplastics

The difference in antibacterial activity of the extract against $E$. coli and $S$. aureus was probably due to different sensitivity toward cell wall structure among microbial (Chana-Thaworn et al. 2011). It is suggested that the antimicrobial activity of bioplastics was obtained from $\mathrm{C}-\mathrm{N}$ covalent bonds of amide groups of NCE. C-N bond has antibacterial properties, where free electrons from $\mathrm{N}$ atoms will attack bacterial DNA (McMurry 2004). But it requires a large electron strength to penetrate the fungal cell wall compared to bacteria so that bioplastics only have the antibacterial ability (McMurry 2004). Thus the use of natural phenolic compounds in food packaging is better because it can improve oxidative food and microbial activities (Aguirre et al. 2013).

In general, FTIR spectrum analysis shows that the fingerprint areas of NC and NCE were comparable with gallic acid. They were characterized by the presence of some groups, such as hydroxyl, carbonyl, ether, ester, and aromatic system (Ajuong and Breese 1998; Gonultas and Ucar 2012). Besides, the presence of $\mathrm{C}-\mathrm{N}$ bonds was also observed at peaks of $72.7 \mathrm{ppm}, 64.0 \mathrm{ppm}, 52.5 \mathrm{ppm}$, and $44.7 \mathrm{ppm}$. It indicated that NC and NCE contained tannin and amide. ${ }^{13} \mathrm{C}$ Nuclear Magnetic Resonance Spectroscopy $\left({ }^{13} \mathrm{C}\right.$ NMR Spectroscopy) analysis has also supported this result.

Besides, NC and NCE inhibited the growth of $E$. coli and $S$. aureus. But only NCE inhibited the growth of $A$. nigger. It is suggested that the presence of phenolic in tannin and amide was responsible as an antimicrobial activity (Rana et al. 2017). However, the result indicated that NC was more sensitive to inhibit bacteria than fungi. This is due to the thickness of chitin in fungi cell walls (Abu et al. 2016). Furthermore, the amide concentration in $\mathrm{NC}$ is still low, so that it was not enough to inhibit the growth of fungi.

Ether groups were also observed in HPS and NCE by FTIR analysis. Since NCE contained ether, carbonyl groups, amides, and hydroxyl (OH) groups, then it is suggested that NCE has a function as a plasticizer and crosslinker. Thus the addition of NCE can reduce the concentration of hydroxyl groups in starch, which can reduce the effect of interference on starch chains to reduce the stiffness and flexibility of bioplastics (Rasheeda et al. 2015). As a result, WS decreased as much as $23.2 \%$ compared to the previous study (Umiyati et al. 2019). WVP decrease by about $38.4 \%$. It is suggested that tannin caused an increase in the hydrophobicity of bioplastics.
Therefore, it inhibited the water absorption of bioplastic and subsequently increased bioplastic resistance to water vapor (Aguirre et al. 2013; Xiang et al. 2015). Thus tannins are polyphenol compounds, which contained several carbonyl groups (Sionkowska et al. 2014), and amide can be used as the natural crosslinking agent.

In conclusion, the results of ${ }^{13} \mathrm{C} N \mathrm{NMR}$ and FTIR analysis showed that the NC and NCE contained tannins and amide groups. Therefore, they had antimicrobial activities toward E. coli and S. aureus. However, only NCE had antifungal toward $A$. nigger. As a consequence, HPS bioplastic containing NCE exhibited antibacterial against $E$. coli and $S$. aureus, but it did not exhibit antifungal toward A. nigger. Moreover, NCE and NC contained carbonyl and amide groups can be found in the bioplastic with the addition of $15 \%$ and $20 \%$ NCE. As a result, NCE addition was able to significantly increase tensile strength of bioplastic, in which it was about 1.5 times higher compared to the control. But it did not have a significant effect on elongation at break and modulus of elasticity. WS and WVP were reduced with an increase in NCE concentration. It is suggested that this is related to the presence of tannin compounds in NCE. HPS-NCE bioplastics show a finer and more homogeneous texture compared to the control. This shows that NCE can function as a natural enhancer for improving bioplastics properties as well as function as antibacterial agent against $E$. coli and $S$. aureus bacteria in bioplastics.

\section{ACKNOWLEDGEMENTS}

The authors would like to acknowledge that this research was funded by Beasiswa Unggulan Dosen Indonesia-Dalam Negeri (BUDI-DN)-Lembaga Pengelola Dana Keuangan (LPDP) of the Indonesian Ministry of Finance.

\section{REFERENCES}

Abu M, Yin H, Isha A, Armania N. 2016. Antioxidant, antimicrobial and cytotoxic potential of condensed tannins from Leucaena leucocephala hybrid-rendang. Food Sci Hum Wellness 5 (2): 65-75.

Agbor VB, Cicek N, Sparling R, Berlin A, Levin DB. 2011. Biomass Pretreatment: Fundamentals toward application. Biotechnol Adv 29 (6): 675-685. 
Aguirre A, Borneo R, Leon AE. 2013. Antimicrobial, mechanical, and barrier properties of triticale protein films incorporated with oregano essential oil. Food Biosci 1: 2-9.

Ajuong EA, Breese MC. 1998. Fourier transform infrared characterization of pai wood (Afzelia africana Smith) extractives. Holz RohWerks 56: $139-142$

Al-Balakocy NG, Shalaby SE. 2018. Imparting antimicrobial properties to polyester and polyamide fibers-state of the art. J Text Assoc 78 (3) 179-201.

Balouiri M, Sadiki M, Ibnsouda SK. 2016. Methods for in vitro evaluating antimicrobial activity: a review. J Pharm Anal 6 (2): 71-79.

Böhm R, Hauptmann M, Pizzi A, Friedrich C, Laborie MP. 2016. The chemical, kinetic, and mechanical characterization of tannin-based adhesives with different crosslinking systems. Intl J Adhes Adhes 68: 1-8.

Chana-Thaworn J, Chanthachum S, Wittaya T. 2011. Properties and antimicrobial activity of edible films incorporated with Kiam wood (Cotyleobium Lanceotatum) extract. LWT-Food Sci Technol 44 (1): 284-292.

Chlebek J, Jun D. 2014. Tannins and Their Influence on Health. In Recen Advances in Medicinal Chemistry, ed. Muhammad Iqbal Choudhary and George Perry Atta-ur-Rahman. Bentham Science, Hradec Kralove.

Detduangchan N, Sridach W, Wittaya T. 2014. Enhancement of the properties of biodegradable rice starch films by using chemical crosslinking agents. Intl Food Res J 21 (3): 1225-1235.

Dos Santos C, Vargas A, Fronza N, dos Santos JHZ. 2017. Structural, textural, and morphological characteristics of tannins from Acacia mearnsii encapsulated using sol-gel methods: applications as antimicrobial agents. Colloids Surf B 151: 26-33.

Elfirta RR, Fallah S, Andrianto D, Lastini T. 2018. Identification of active compounds and antifungal activity of Toona sinensis leaves fractions against wood rot fungi. Biodiversitas 19: 1313-1318.

El-Tahlawy K, Venditti RA, Pawlak JJ. 2007. Aspects of the preparation of starch microcellular foam particles crosslinked with glutaraldehyde using a solvent exchange technique. Carbohydr Polym 67 (3): 319 331.

Espinel RA, Flores SK, Gerschenson LN. 2014. Biopolymeric antimicrobial films: study of the influence of hydroxypropyl methylcellulose, tapioca starch, and glycerol contents on physical properties. Mater Sci Eng C 36: 108-117.

Falcão L, Araújo MEM. 2011. Tannins characterization in new and historic vegetable-tanned leather fibres by spot tests. J Cult Heritage 12 (2): $149-156$

Gallstedt M, Hedenqvist MS, Ture H. 2011. Production, Chemistry, and Properties of Proteins. Biopolymers-New Materials for Sustainable Films and Coatings. John Wiley \& Sons, New Jersey.

Gonultas O, Ucar MB. 2012. Chemical composition of some commercial tannins produced in Turkey. Proceedings of the $55^{\text {th }}$ International Convention of Society of Wood Science and Technology, Beijing 27 31 August 2012. (China)

Grasel FdS, Wolf CR. 2016. Development of methodology for identification the nature of the polyphenolic extracts by FTIR associated with multivariate analysis. Spectrochim Acta-Part A: Molecular and Biomolecular Spectroscopy 153: 94-101

Hassannia-kolaee M, Khodaiyan F, Pourahmad R, Ghahfarrokhi IS. 2016 Development of ecofriendly bionanocomposite: whey protein isolate/pullulan films with nano-SiO2. Intl J Biol Macromol 86: 139144.

Hien M, Nguyen VT, Quynh K, Nguyen C. 2009. Antimicrobial activity of Calophyllum inophyllum crude extracts obtained by pressurized liquid extraction. Asian J Traditional Med 4 (4): 141-146.

Kim HY, Jane JL, Lamsal B. 2017. Hydroxypropylation improves film properties of high amylose corn starch. Ind Crops Prod 95: 175-183.

Kumari M, Mahajan H, Joshi R, Gupta M. 2017. Development and structural characterization of edible films for improving fruit quality. Food Packaging Shelf Life 12: 42-50

Malhotra B, Keshwani A, Kharkwal H. 2015. Antimicrobial food packaging: potential and pitfalls. Front Microbiol 6: 1-9.

Manoi K, Rizvi SSH. 2010. Physicochemical characteristics of phosphorylated cross-linked starch produced by reactive supercritical fluid extrusion. Carbohydr Polym 81: 687-694.

McMurry J. 2004. Organic Chemistry (International Edition). $8^{\text {th }}$ ed. eds. Thomson Learning, Belmont, CA.
Mishra US, Murthy PN, Choudhury PK, Panigrahi G, Mohapatra S, Pradhan D. 2010. Antibacterial and analgesic effects of the stem barks of Calophyllum inophyllum. Intl J ChemTech Res 2 (2): 973-979.

Peelman N, Ragaerta P, Meulenaer BD, Adons D, Peeters R, Cardond L, Impe FV, Devlieghere F. 2013. Application of bioplastics for food packaging. Trends Food Sci Technol 32 (2): 128-141.

Piermaria J, Bosch A, Pinotti A, Yantorno O, Garcia MA, Abraham AG. 2011. Kefiran films plasticized with sugars and polyols : water vapor barrier and mechanical properties in relation to their microstructure analyzed by ATR/FT-IR Spectroscopy. Food Hydrocoll 25 (5): 12611269.

Pinazo A, Manresa MA, Marques AM, Bustelo M, Espuny MJ, Pérez L. 2016. Amino acid-based surfactants: new antimicrobial agents. Adv Colloid Interface Sci 228: 17-39.

Plackett D. 2011. Biopolymers-New Materials for Sustainable Films and Coatings. John Wiley \& Sons, New Jersey.

Radebe N, Rode K, Pizzi A, Giovando S, Pasch H. 2012. MALDI-TOFCID for the microstructure elucidation of polymeric hydrolysable tannins. J Appl Polym Sci: 1-11.

Rana R, Amin NI, An Naser A, Islam N. 2017. Screening of Calophyllum inophyllum L. leaf extracts for cytotoxic, larvicidal, insect repellent, and antimicrobial activities. J Pharm Phytoche 6 (3): 612-616.

Rasheeda F, Hedenqvist MS, Kuktaite R, Plivelic TS, Gällstedt M, Johansson E. 2015. Mild gluten separation - a non-destructive approach to fine-tune structure and mechanical behavior of wheat gluten films. Ind Crops Prod 73: 90-98.

Rath SC, Nayak KC, Pradhan C, Mohanty TK, Sarkar S, Toppo S, Mohanta KN, Giri SS. 2017. Evaluation of Polanga (Calophyllum inophyllum) oil cake as a non-conventional ingredient in Labeo rohita (Hamilton, 1822) fingerling feed. Indian J Fisheries 64 (76207): 75 82.

Ricci A, Olejar KJ, Parpinello GP, Kilmartin PA, Versari A. 2015. Application of Fourier Transform Infrared (FTIR) Spectroscopy in the characterization of tannins. Appl Spectrosc Rev 50 (5): 407-442.

Seelig J. 2010. 13C NMR Spectroscopy. In Annual Reports on NMR Spectroscopy. https://www.sciencedirect.com/topics/chemistry/13cnmr-spectroscopy

Shahat AA, Marzouk MS. 2013. Tannins and related compounds from medicinal plants of Africa. In: Medicinal Plant Research in Africa Tannins and Related Compounds from Medicinal Plants of Africa. Elsevier Inc, Amsterdam.

Sionkowska A, Kaczmarek B, Lewandowska K. 2014. Characterization of chitosan after cross-linking by tannic acid. Progress on Chemistry and Application of Chitin and Its Derivatives 29: 135-138.

Socrates G. 2004. Infrared and Raman Characteristic Group Frequencies. John Wiley \& Sons, New Jersey.

Spec-Chem Ind. 2014. Sodium Hyaluronate: 1-15. (patent).

Sulianti SB, Kuncari ES, Chairul SM. 2005. Pemeriksaan farmakognosi dan penapisan fitokimia dari daun dan kulit batang Calophyllum inophyllum dan Calophyllum soulatri. Biodiversitas 7 (1): 25-29.

Sundur S, Shrivastava B, Sharma P, Raj SS, Jayasekhar VL. 2014. A Review article of pharmacological activities and biological importance of Calophyllum inophyllum. Intl J Adv Res 2 (12): 599603.

Sung SY, Sin LT, Tee TT, Bee ST, Rahmat AR, Rahman WA, Tan AC, Vikhraman M. 2013. Antimicrobial agents for food packaging applications. Trends Food Sci Technol 33 (2): 110-123.

Umiyati R, Hidayat C, Millati R, Ariyanto T. 2019. Physical and antimicrobial properties of hydroxypropyl starch bio-plastics incorporated with nyamplung (Calophyllum inophyllum) cake extract as an environmentally friendly food packaging. Proceeding of the $4^{\text {th }}$ International Conference on Energy, Environment, Epidemiology and Information System, Universitas Diponegoro, Semarang 7-8 August 2019. [Indonesian]

Wang L. 2015. Properties of Flexible Films Made of Hemicellulose [Dissertation]. Michigan State University. (USA)

Wirawan SK, Prasetya A, Ernie E. 2012. Pengaruh plasticizer pada karakteristik edible film dari pektin. Reaktor 14 (1): 61-67. [Indonesian]

Xiang H, Li L, Wang S, Wang R, Cheng Y, Zhou Z, Zhu M. 2015. Natural polyphenol tannic acid reinforced composite films with enhanced tensile strength and fracture toughness. Polym Compos 36: 2303-2308.

Zubeldía F, Ansorena MR, Marcovich NE. 2015. Wheat gluten films obtained by compression molding. Polym Test 43: 68-77. 